\title{
Research on Strategic Performance Evaluation of Bright Dairy
}

\author{
Maomao Chen \\ School of Economics and Management \\ Nanjing University of Science and Technology \\ Nanjing, China
}

\begin{abstract}
As an effective performance evaluation system, Balanced Score Card has always been a hot topic in academic research. It shows the strategic trajectory of the organization through the interrelated causal relationship between financial, customer, internal processes and learning and development. Balanced Score Card is the most popular performance evaluation system, but there are still some problems that can't be neglected in practical application. Based on the analysis of domestic and foreign scholars' research, this paper takes Bright Dairy as the research object and embeds social responsibility into the BSC theory, trying to build a more comprehensive strategic performance evaluation system to be in line with the requirements of the times. The combination of quantitative and qualitative indicators can be more reasonable and comprehensive to discover the advantages and disadvantages of enterprises, to improve the level of business management through timely feedback and strategic adjustment, and ultimately to achieve the strategic objectives of enterprises, which is theoretically and practically significant.
\end{abstract}

Keywords-Balanced Score Card; Social Responsibility; Bright Dairy

\section{INTRODUCTION}

The rapid development of economic globalization in recent years has been accompanied by a growing number of companies facing more fierce market competition and complex environment. To win a place in the fierce market competition, it is necessary to change the way of enterprise performance appraisal in time, pay more attention to achieve long-term interests of the maximization. This requires enterprises from the strategic perspective, taking into account the financial factors and non-financial factors, in line with their own characteristics, establish a strategic performance evaluation system. Many managers pay attention to the role of strategic objectives in the enterprise performance evaluation, and give advice for the sustainable development of the enterprise. Therefore, the performance evaluation has gradually become a strategic move to enhance corporate strategic management capabilities, cultivate competitive advantage.

With the rapid development of China's economy and people's living standards, dairy products have become an important daily consumer goods, dairy industry has entered a period of rapid development. However, in recent years dairy companies may suffer from an unprecedented crisis of confidence due to the melamine scandal. Therefore, the dairy industry's social responsibility has become the focus of attention and we need to consider social responsibility in evaluating the strategic performance of the dairy industry.

\section{LITERATURE REVIEW}

In the middle of the 20th century, American management expert Peter M. Drucker first proposed eight indicators of enterprise performance evaluation, including market position, innovation, productivity, and social responsibility. Drucker believes that profit maximization should be the main goal of business, but should not be the only goal. Although it does not form a complete set of performance evaluation theory model, but this evaluation method has begun to pay attention to corporate social responsibility and long-term development

In 1992, Professor Kaplan and Norton presented the famous "Balanced Score Card" theory, including finance, customer, internal management and learning and growth. BSC enables managers to utilize important non-financial as well as financial measures, in performance information in evaluations. However, in practical applications, the Balanced Score Card is often more suitable for large groups or enterprises, the setting of indicators is sometimes difficult to determine.

For a long time, our country's performance evaluation research is led by the government, which has formed a financial performance-based performance evaluation system. Before the 21st century, China's performance evaluation system has undergone many adjustments, but most of them emphasize on financial indicators, did not take into account the modern enterprise development needs of non-financial indicators.

In recent years, Non-financial indicators are becoming increasingly important in the role of performance evaluation. At present, domestic scholars draw on the advanced performance evaluation theory, combined with the actual situation of China's enterprises, put forward many different ideas: Liu Yali (2003) from investors, the government, consumers and the public and other stakeholders point of view studied the economic performance evaluation system, the social performance evaluation system, the risk performance evaluation system and the environmental performance evaluation system of the natural monopoly 
enterprises separately, and has added the market value increment rate index in it [1]. Xu Guanghua (2007) studied symbiosis theory, innovatively put forward the conception of symbiosis strategy performance evaluation mode, and integrated corporate social responsibility into enterprise strategic performance evaluation system so as to achieve the harmonious coexistence and sustainable development of enterprises and society [2]. After comparing the advantages and disadvantages of EVA and BSC theory, Liu Qian (2009) proposed the organic integration of EVA and BSC, and constructed the index system of enterprise strategic performance including the leading index and lagging index [3]. Chang Shuchun (2009) thought that the financial-based traditional performance evaluation index system is not comprehensive enough, which is easy to ignore the external factors and future development, it should be in the performance evaluation index system to add non-financial indicators to reflect the future development potential [4].

At the same time, some domestic scholars have also made different views on the traditional enterprise performance evaluation system, pointing out its shortcomings. Zhang Rui (2002) analyzed and evaluated the Balanced Score Card system, and put forward the whole framework of the evaluation index system of enterprise strategic management performance [5]. Ma Lu (2004) proposed an improved DuPont financial analysis model, the paper constructs non-financial performance evaluation index system based on customer value innovation, core business process and learning and innovation, and analyzes and demonstrates the correlation between the indicators, so as to combine the financial and non-financial indicators organically [6].

In summary, the domestic academic community pays more and more attention to the performance evaluation index system research. But it is not difficult to find that many of research literatures are not strong enough in innovation. Most of them only stay in absorbing and discussing the achievements of research abroad, and the performance evaluation system should be perfected in practice. Although some scholars have begun to consider social responsibility, ecological environment and other factors, but most of the performance evaluation system is still based on financial performance as the core, non-financial indicators is still relatively small, which can't fully measure the status of corporate social responsibility. In addition, the domestic research literature on the evaluation of performance evaluation methods rarely combined with industry characteristics. There have been many problems especially in the dairy industry and other fast moving consumer goods industry, which is the significance of this study.

Therefore, in the selection of indicators of strategic performance evaluation, enterprises should establish the concept of symbiotic harmony, and attach importance to fulfill the important obligation of social responsibility.

\section{CURRENT SITUATION OF BRIGHT DAIRY}

Bright Dairy is a Well-known enterprise in China with development, production and marketing of all types of dairy products as the main business. This brand originated in 1950 and experienced more than 60 years of continuous development. In 2000, Bright Dairy completed the shareholding system reform, and in 2002 successfully listed. At present, Bright Dairy has become the domestic dairy industry's well-known brands, but also one of the largest domestic dairy enterprises.

In recent years, Bright Dairy launched some popular products, and the company's operating profits are rising, but with the rising cost of the acquisition of raw milk and logistics, the dairy market competition is becoming increasingly fierce. Due to its strong regional, Bright Dairy's market share and brand recognition rate still have a certain gap with Mengniu, Yili and other first-line brands. In terms of performance evaluation, the performance management of the enterprise is limited to simple performance evaluation, the business process and management is not perfect, and there are some problems, mainly in the following areas.

\section{A. The Company's Key Performance Indicators Are too Simple}

Dairy industry belongs to the fast moving consumer goods industry, integrates production, sales and service as a whole, the company's products include not only the quality of dairy products, but also includes the brand image and quality of service. Customer satisfaction with dairy products, services, and sales environment is critical. At the same time, the research and development of new products, the training coverage of employees and the fulfillment of corporate social responsibility are the key to whether enterprises can obtain long-term core competitiveness. The performance indicators set by Bright Dairy is not perfect enough to evaluate the overall behavior of the company, there is a certain lag.

\section{B. The Department's Performance Indicators Formalized}

Some sector performance indicators are too one-sided and single. Most are the quantitative indicators to evaluate corporate financial performance, not really implemented to the post, affecting the enthusiasm of enterprise employees. In addition, people can't measure the work of corporate social responsibility and environmental protection because of lacking of perfect feedback mechanism, which is not conducive to long-term development of enterprises.

\section{Performance Evaluation Process without the \\ Participation of Employees and Customers}

Performance evaluation process is a link throughout the daily work of enterprises. Performance evaluation is not only to measure the completion of the work for the staff, but also to ask the staff for the degree of recognition and satisfaction with work environment and corporate culture. In addition, customer satisfaction is also an important factor in determining the company's development. Enterprises should set this indicator to examine their own strengths and weaknesses, listen to the views and ideas of customers, then improve. With the participation of customers, employees, appraisers and other aspects, the whole process of setting performance indicators and performance evaluation will be 
more reasonable and more comprehensive, and will achieve good results.

\section{Strategic Performance EVAluation}

Combined with the actual situation of Bright Dairy, we can build a strategic performance evaluation index system.

\section{A. Sources of Data}

The quantitative indicators of enterprise strategy performance evaluation mainly come from Shanghai Stock Exchange, information websites of listed companies, Sina Finance and other websites. Specifically, the four indicators (ROE, cost margin, sales growth rate and net cash flow liabilities ratio) are derived from the Shanghai Stock Exchange database, the rest indicators are derived from the official website of Bright Dairy and corporate public disclosure Such as annual reports, semi-annual reports and other periodic reports, interim announcements and annual social responsibility reports.

The scoring of the index weight mainly obtained through questionnaire and other forms. Scoring is mainly used 1-9 scale ratio method. After the appropriate amendment of relevant index system and scoring status, the weights of each index are averaged and the uniform weight of each evaluation index is determined.

\section{B. Indicator Design and Variable Selection}

At present, the lack of corporate social responsibility of dairy products has become an urgent need to address the problem. Therefore, the construction of a scientific performance evaluation system to carry out examination and supervision on corporate social responsibility is very important. This paper combines the four dimensions of BSC with social responsibility. According to the principle of adaptability, this paper tries to construct a strategic performance evaluation system suitable for the development of enterprises. Relevant indicators are measured as follows.

\section{1) Financial performance}

a) Return on equity: The ratio of the after-tax profit to the average net assets, which reflects the level of return on shareholders' equity. According to Bright Dairy's 2014 Annual Report, by the end of 2014, Bright Dairy has net profit of 583.058 million yuan, total assets of 12.83 million yuan, net assets yield of about $12.59 \%$.

b) Ratio of profits to cost: According to Bright Dairy 2014 Annual Report, its cost margins of about 3.6526\%.

c) Sales revenue growth rate: By the end of 2014, the company's sales revenue growth rate is about $25.1315 \%$.

d) Net cash flow liabilities ratio: The ratio of the net cash flow from operating activities to total liabilities. From the perspective of cash flow to reflect the current capacity of enterprises to repay short-term liabilities. By the end of 2014 , bright dairy net cash flow liabilities ratio of about $0.0437 \%$

\section{2) Customer performance}

a) Market share: Refers to a company's sales (amount) in the proportion of the entire industry. This indicator reflects the competitive position and profitability of the enterprise to a great extent. From the securities company's report, in 2014, the overall market share of Bright Dairy is about $21.3 \%$.

b) The number of customer complaints: The total number of complaints received. in 2014, Bright Dairy received complaints about the total number of 34,810 calls.

c) Complaint resolution rate: From the bright dairy social responsibility report that in 2014, bright dairy problem resolution for the complaint rate of about $99.74 \%$.

d) Customer satisfaction: The customer's satisfaction or repeat purchase level for the bright dairy products, Which is a qualitative indicator and can be evaluated from the aspects of product, service, image and performance.

\section{3) Internal operational performance}

a) Product qualification rate: The number of qualified products divided by the total output, which reflects the company's product quality. According to Bright Dairy Social Responsibility Report, by the end of 2014, the market supervision departments at all levels have a total sampling of 3061 times, and the qualified rate is $99.97 \%$.

b) Quality level: Is a qualitative index, which is determined by the company's third-party quality system certification and market research.

c) Intangible assets ratio: Refers to the ratio of intangible assets to total assets. According to Bright Dairy 2014 Annual Report, the company intangible assets of 312.396 million yuan, the total assets of 128.8110 million yuan, the ratio of intangible assets is about $2.42 \%$.

d) $R \& D$ expense ratio: The ratio of the total expenses of the enterprise used for R \& D in the year to the total sales income. Bright Dairy 2014 annual report shows that corporate $\mathrm{R} \& \mathrm{D}$ expense ratio of about 0.22 .

\section{4) Learning and growth performance}

a) Training coverage: That is, the number of people receiving skills training divided by the total number of employees. According to the Corporate Social Responsibility Report 2014, the company has 4459 employees in service, and the total number of in-house training courses in the business divisions in 2014 was 63, with a total of 1798 attendees. Training coverage is about $40.32 \%$.

b) Overall labor productivity: Refers to the ratio of the main business income to the total number of employees. According to the annual report of the Company for 2014, Bright Dairy 's main business income is about RMB 20385100000, and the labor productivity is 457.17 .

c) Technical staff ratio: Refers to the ratio of the number of technical staff to the total number of employees. Bright Dairy's technical staff ratio is about $13 \%$. 
d) Employee satisfaction: Refers to the evaluation of the staff on the work environment, development space, pay and other aspects, which can use questionnaire to evaluate.

\section{5) Social responsibility performance}

a) Environmental contribution rate: According to the Corporation Social Responsibility (CSR) report, the completion of industrial energy-saving targets in 2014 of Bright Dairy: the total energy consumption is 47524.01 tons of standard coal; energy consumption per unit of industrial output is 0.0721 tons of standard coal, down $5.13 \%$ compared with a year earlier, and it completed the annual energy-saving targets issued by Shareholders.

b) Environmental yield: Reflects the development of environmental investment and environmental technology in enterprises. In 2014, the national plants of Bright Dairy have a total investment of 79.47 million yuan for environmental protection and technological transformation projects, which have saved the annual cost of 682300 yuan and the annual energy consumption of 351.03 tons of standard coal.

c) Tax contribution rate: Refers to the ratio of corporate tax payable to the average total assets. In 2014, the tax contribution rate of Bright Dairy is about $2.14 \%$.

d) Employment contribution rate: According to the Company's annual report, by the end of 2014, the net assets of Bright Dairy was RMB 1288.31 million and the salary paid to employees was approximately RMB 2068.42 million. Therefore, the employment contribution rate of the Company was approximately $1.6 \%$.

\section{Fuzzy Synthetic Evaluation Method}

1) Single-factor evaluation: The evaluation grades were divided into five grades: excellent, good, middle, low and poor, of which 90 points and above were excellent, 70-89 was good, 50-69 was classified as middle and 30-49 is divided into low, 0-29 is divided into poor. The scores are averaged for each file. So we set the evaluation set as: $\mathrm{V}=$ [v1 v2 v3 v4 v5] = [95 806040 15]. The evaluation results as shown in the table below. "Table I"
TABLE I. Single FACTOR EVALUATION RESUlTS

\begin{tabular}{|c|c|c|c|c|c|c|}
\hline \multirow{2}{*}{$\begin{array}{c}\text { Criterion } \\
\text { layer }\end{array}$} & \multirow{2}{*}{$\begin{array}{c}\begin{array}{l}\text { Index } \\
\text { layer }\end{array} \\
\end{array}$} & \multicolumn{5}{|c|}{ Single-factor evaluation } \\
\hline & & Excellent & Good & Middle & Low & Poor \\
\hline \multirow{4}{*}{$\begin{array}{l}\text { Financial } \\
\text { dimension (X1) }\end{array}$} & $\begin{array}{l}\text { Return on } \\
\text { Equity }\end{array}$ & 0.2 & 0.5 & 0.3 & 0 & 0 \\
\hline & $\begin{array}{l}\text { Cost rate of } \\
\text { profit }\end{array}$ & 0.2 & 0.4 & 0.4 & 0 & 0 \\
\hline & $\begin{array}{l}\text { Sales growth } \\
\text { rate }\end{array}$ & 0.6 & 0.3 & 0.1 & 0 & 0 \\
\hline & $\begin{array}{l}\text { Net cash flow } \\
\text { liabilities ratio }\end{array}$ & 0.2 & 0.6 & 0.2 & 0 & 0 \\
\hline \multirow{4}{*}{$\begin{array}{l}\text { Customer } \\
\text { dimension (X2) }\end{array}$} & Market share & 0.2 & 0.6 & 0.2 & 0 & 0 \\
\hline & $\begin{array}{l}\text { Number of } \\
\text { customer } \\
\text { complaints }\end{array}$ & 0.1 & 0.2 & 0 & 0.7 & 0 \\
\hline & $\begin{array}{ll}\text { Rate } & \text { of } \\
\text { complaint } & \\
\text { resolution } & \\
\end{array}$ & 0.5 & 0.3 & 0.2 & 0 & 0 \\
\hline & $\begin{array}{l}\text { Customer } \\
\text { satisfaction }\end{array}$ & 0.3 & 0.6 & 0.1 & 0 & 0 \\
\hline \multirow{4}{*}{$\begin{array}{l}\text { Internal process } \\
\text { dimension (X3) }\end{array}$} & $\begin{array}{ll}\text { Rate } & \text { of } \\
\text { qualified } & \\
\text { products } & \\
\end{array}$ & 0.3 & 0.2 & 0.5 & 0 & 0 \\
\hline & $\begin{array}{l}\text { Ratio of } \\
\text { intangible } \\
\text { assets }\end{array}$ & 0.3 & 0.5 & 0.2 & 0 & 0 \\
\hline & Quality level & 0.4 & 0.5 & 0.1 & 0 & 0 \\
\hline & $\begin{array}{l}\mathrm{R} \& \mathrm{D} \\
\text { expense ratio }\end{array}$ & 0.7 & 0.2 & 0.1 & 0 & 0 \\
\hline \multirow{4}{*}{$\begin{array}{l}\text { Learning and } \\
\text { Growth } \\
\text { dimensions(X4) }\end{array}$} & $\begin{array}{l}\text { Training } \\
\text { Coverage }\end{array}$ & 0 & 0.2 & 0 & 0.5 & 0.3 \\
\hline & $\begin{array}{l}\text { Total Labor } \\
\text { Productivity }\end{array}$ & 0.3 & 0.5 & 0.2 & 0 & 0 \\
\hline & $\begin{array}{l}\text { Technical } \\
\text { staff ratio }\end{array}$ & 0.4 & 0.5 & 0.1 & 0 & 0 \\
\hline & $\begin{array}{l}\text { Employee } \\
\text { satisfaction }\end{array}$ & 0.8 & 0.2 & 0 & 0 & 0 \\
\hline \multirow{4}{*}{$\begin{array}{l}\text { Social } \\
\text { responsibility } \\
\text { dimension (X5) }\end{array}$} & $\begin{array}{l}\text { Environmental } \\
\text { contribution } \\
\text { rate }\end{array}$ & 0.7 & 0.2 & 0.1 & 0 & 0.3 \\
\hline & $\begin{array}{l}\text { Environmental } \\
\text { yield }\end{array}$ & 0.8 & 0.1 & 0.1 & 0 & 0 \\
\hline & $\begin{array}{l}\text { Contribution } \\
\text { rate of tax } \\
\text { payment }\end{array}$ & 0 & 0.1 & 0.3 & 0.6 & 0 \\
\hline & $\begin{array}{l}\text { Employment } \\
\text { contribution } \\
\text { rate }\end{array}$ & 0.5 & 0.2 & 0.3 & 0 & 0 \\
\hline
\end{tabular}

2) Fuzzy calculation: The evaluation matrix of five dimensions can be obtained from the above table:

$$
\mathrm{R}(X 1)=\left[\begin{array}{lllll}
0.2 & 0.5 & 0.3 & 0 & 0 \\
0.2 & 0.4 & 0.4 & 0 & 0 \\
0.6 & 0.3 & 0.1 & 0 & 0 \\
0.2 & 0.6 & 0.2 & 0 & 0
\end{array}\right]
$$

The weight distribution of the five dimensions is shown as follows:

$$
W=\left[\begin{array}{lllll}
0.413 & 0.206 & 0.206 & 0.109 & 0.065
\end{array}\right]
$$

Similarly, we can obtain the weight distribution of the indicator layer under other dimensions. For the convenience of calculation, we call the eigenvectors of financial dimension, customer dimension, internal process dimension, learning and growth dimension and social responsibility dimension as $\mathrm{W} 1, \mathrm{~W} 2, \mathrm{~W} 3, \mathrm{~W} 4, \mathrm{~W} 5$ respectively, after the 
same calculation and consistency test, the results are as follows:

$$
\begin{aligned}
& W 1=\left[\begin{array}{llll}
0.138 & 0.447 & 0.288 & 0.127
\end{array}\right] \\
& W 2=\left[\begin{array}{llll}
0.328 & 0.276 & 0.253 & 0.143
\end{array}\right] \\
& W 3=\left[\begin{array}{llll}
0.387 & 0.105 & 0.244 & 0.264
\end{array}\right] \\
& W 4=\left[\begin{array}{llll}
0.224 & 0.347 & 0.222 & 0.207
\end{array}\right] \\
& W 5=\left[\begin{array}{llll}
0.370 & 0.345 & 0.185 & 0.100
\end{array}\right]
\end{aligned}
$$

Then, we can obtain the results:

$$
\begin{aligned}
U 1 & =W 1 \times R(X 1)=\left[\begin{array}{lllll}
0.3152 & 0.4104 & 0.2744 & 0 & 0
\end{array}\right] \\
U 2 & =\left[\begin{array}{lllll}
0.2626 & 0.4137 & 0.1305 & 0.1932 & 0
\end{array}\right] \\
U 3 & =\left[\begin{array}{lllll}
0.4301 & 0.3046 & 0.2653 & 0 & 0
\end{array}\right] \\
U 4 & =\left[\begin{array}{lllll}
0.3585 & 0.3707 & 0.0916 & 0.1120 & 0.0672
\end{array}\right] \\
U 5 & =\left[\begin{array}{lllll}
0.5850 & 0.1470 & 0.1570 & 0.1110 & 0
\end{array}\right]
\end{aligned}
$$

Then, the fuzzy comprehensive evaluation matrix of the criterion layer is obtained:

$$
\begin{aligned}
& \mathrm{R}=\left[\begin{array}{llllll}
\mathrm{U} 1 & \mathrm{U} 2 & \mathrm{U} 3 & \mathrm{U} 4 & \mathrm{U} 5
\end{array}\right]^{\mathrm{T}} \\
& \mathrm{U}=\mathrm{W} \times \mathrm{R}=\left[\begin{array}{llllll}
0.35 & 0.3674 & 0.2151 & 0.0592 & 0.0073
\end{array}\right]
\end{aligned}
$$

According to the above analysis, we can draw the conclusion that the proportion of "excellent" is 35\%, "good" is $36.74 \%$, "middle" is $21.51 \%$ and "low" is $5.92 \%$, The difference is $0.73 \%$. According to the principle of maximum subordination, the results of strategic performance evaluation of Bright Dairy are "good". To determine the company's strategic performance evaluation status in the industry, we need to calculate the final evaluation score.

$$
Z=U \times V^{T}=78.02
$$

In accordance with the evaluation score, 78.02 is in the range of 70 to 89 , so the company's final evaluation score is at a "good" level.

\section{CONCLUSIONS}

Enterprise strategic performance evaluation is not only an analysis and summary of the past achievements, but also an important step to guide enterprises to formulate and implement the strategy, so as to realize the sustainable development of enterprises and the strategic target of "bigger and stronger". Based on the actual situation of the enterprise and the characteristics of the dairy industry, this paper chooses the concrete performance evaluation index, determines the weight of each dimension through analytic hierarchy process, and finally adopts fuzzy comprehensive evaluation method to evaluate the strategic performance of Bright Dairy.

Overall, Bright Dairy's financial performance is relatively good. Compared with other indicators, training coverage and employment contribution rate is relatively backward. This shows that enterprises in the staff level also need to pay more attention to improve the staff's ability and knowledge. Bright Dairy's market share is about $21.3 \%$, ranking in the dairy industry in the more front, which is inseparable from the company's brand building over the years.

Based on the above research results, this paper attempts to give the following suggestions:

- First, to promote food safety traceability system, establish a comprehensive dairy quality and safety monitoring system which covering milk production, circulation, dairy processing, marketing and sales of all aspects to improve the quality of the original milk pass rate and qualified products Rate, in the community to establish a good business reputation and effectively fulfill their social responsibility.

- Second, with the Chinese people's living standards gradually increased, dairy consumer market will continue to expand and become more mature. In such a broad market prospects, the dairy production enterprises must maintain a strong sense of product quality innovation in order to become an eternal winner. Therefore, the dairy enterprises in order to firmly occupy the market, they must have highquality milk, strict health management mechanism and a high level of preservation technology. Which need to rely on high-tech to constantly improve and enhance the quality of dairy products.

- Third, to deal with the rising cost pressure from raw milk acquisition and logistics, enterprises are not only the price increase this way to go, but should gather the strength of enterprises from top to bottom, optimize the industrial structure, and strive to achieve product differentiation. And only the product itself, including taste, function and the corresponding brand services, is the real value for consumers to create.

- Fourth, enterprises should be based on their own advantages, seize the opportunity to meet the challenges, maintain and consolidate the core competitiveness. In addition, companies should also make full market research work, continue to segment the market, open up the market, tap new consumer groups, to win a wider range of customers.

- Fifth, according to the actual situation of enterprises, we can choose the appropriate evaluation index according to the research methods used in this paper, determine the corresponding weight according to the actual data, build a strategic performance evaluation system for enterprise development to have an objective and fair performance evaluation, then feedback and adjust according to the evaluation results.

- Sixth, pay attention to the contribution to the environment, improve the initiative to assume social responsibility as much as possible, consider the social responsibility in the enterprise's strategic planning. Through the annual corporate social responsibility report, disclosure a true and detailed report to the public. 
This article also has some shortcomings. Due to the limitations of the reference materials, the performance evaluation system selected in this paper has some qualitative indicators, which need to be assessed by means of questionnaires. In addition, this article only for bright dairy to conduct a specific analysis, and the establishment of evaluation system which can be applied to different enterprise in the whole industry needs further study.

\section{ACKNOWLEDGMENT}

Thanks for the guidance and help from my mentor Liu Shiping and my classmates.

\section{REFERENCES}

[1] Liu Yali, "On the improvement of the accounting responsibility and financial report of natural monopoly enterprises -- Taking electric power enterprises as an example,"Accounting Research,vol.8, pp. 4548, 2003.

[2] Xu Guanghua, "Model of strategic performance evaluation: Research on the embedded nature of corporate social responsibility,"Management World,vol.11, pp. 166-167, 2009.

[3] Liu Qian, "A discussion on the construction of enterprise strategic performance evaluation system framework,"Modern Finance and Economics, vol.7, pp. 48-50, 2009.

[4] Chang Shuchun, "Study on Performance Evaluation of Modern Enterprise Financial Strategy," Business Research,vol.9, pp. 96-99, 2009.

[5] Zhang Rui,"Changes in the Theories and Methods of Business Performance Evaluation," Accounting Research,vol.12, pp. 46-50, 2001.

[6] Ma Lu, "Study on Enterprise Strategic Performance Evaluation System," Economic Management Press, 2004. 